\title{
Diagnostic difficulties of paroxysmal symptoms in a boy with Parry-Romberg syndrome
}

\section{Trudności diagnostyczne objawów napadowych u chłopca z zespołem Parry'ego-Romberga}

Marek Kaciński, Agnieszka Biedroń, Anna Zając, Małgorzata Steczkowska

Chair of Paediatric and Adolescent Neurology, Jagiellonian University Collegium Medicum, Kraków

Neurologia i Neurochirurgia Polska 2010; 44, 3: 297-303

\begin{abstract}
Parry-Romberg syndrome is characterized by progressive unilateral facial atrophy affecting subcutaneous tissue, cartilage and bone structures. Headache attacks and epilepsy are commonly associated with this syndrome but the underlying pathophysiology is still unknown. A case of a 12-year-old boy with Parry-Romberg syndrome and syringomyelia suffering from severe headache attacks and epileptic seizures is reported herein.

Headache attacks were associated with bilateral autonomic symptoms and hyperventilation and were usually followed by complex partial and sometimes by secondary generalized tonic seizures. Detailed neuroimaging examinations were performed (magnetic resonance imaging [MRI] of the head, orbits, and spinal cord, MR angiography, and MR spectroscopy of the cerebellum). The EEG pattern revealed localized discharges contralaterally to the affected side. Antiepileptic treatment with carbamazepine was instituted with minimal effect. Modification of treatment (replacement with oxcarbazepine) was successful.

In the reported patient interesting correlation of headache attacks, autonomic symptoms and epileptic seizures was observed. Additionally we believe it is the first report of coincident syringomyelia and Parry-Romberg syndrome.
\end{abstract}

Key words: Parry-Romberg syndrome, facial hemiatrophy, headache, epilepsy, syringomyelia.

\section{Streszczenie}

Zespół Parry’ego-Romberga charakteryzuje się postępującym zanikiem połowy twarzy, obejmującym tkankę podskórną, chrząstkę oraz struktury kostne. $\mathrm{Z}$ zespołem tym często związane są bóle głowy oraz padaczka, jednakże leżąca u ich podstawy patofizjologia nadal nie jest znana. W niniejszej pracy przedstawiono przypadek dotyczący 12-letniego chłopca z zespołem Parry'ego-Romberga i jamistością rdzenia, u którego występowały napady bardzo silnych bólów głowy oraz napady padaczkowe.

Napadom bólów głowy towarzyszyły obustronne objawy autonomiczne oraz hiperwentylacja, po których zazwyczaj występowały napady częściowe złożone, a czasami wtórnie uogólnione napady toniczne. Przeprowadzono szczegółową diagnostykę obrazową [badanie za pomocą rezonansu magnetycznego (RM) głowy, oczodołów i rdzenia kręgowego, angiografię RM głowy i spektroskopię RM móżdżku]. EEG wykazał zmiany zlokalizowane po stronie przeciwnej do zajętej procesem chorobowym. Wdrożono leczenie przeciwpadaczkowe karbamazepiną, którego początkowy efekt był niewielki. Zamiana leku na okskarbazepinę okazała się skuteczna. $\mathrm{U}$ opisanego pacjenta zaobserwowano interesujący związek napadów bólów głowy, objawów autonomicznych i napadów padaczkowych. Jest to prawdopodobnie pierwszy opis zespołu Parry'ego-Romberga z towarzyszącą jamistością rdzenia.

Słowa kluczowe: zespół Parry’ego-Romberga, połowiczy zanik twarzy, ból głowy, padaczka, jamistość rdzenia.

Correspondence address: Prof. Marek Kaciński, Katedra Neurologii Dzieci i Młodzieży UJ CM, ul. Wielicka 265, 30-663 Kraków, phone/fax: + 481265818 70, e-mail: neupedkr@cm-uj.krakow.pl

Received: 31.10.2009; accepted: 18.03.2010 


\section{Introduction}

The majority of patients with progressive facial hemiatrophy (Parry-Romberg syndrome, PRS) are affected at developmental age. Progressive destruction concerns the subcutaneous tissue, cartilage and bone structures. Various neurological (seizures, migraine-type headache, trigeminalgia) and ophthalmological manifestations have been observed in this syndrome and they sometimes occurred prior to the facial hemiatrophy $[1,2]$. Other neurological disorders reported include bilateral pyramidal tract impairment [3], progressive cerebral hemisphere atrophy and fatal brain stem involvement [4], dysphonia [5], diplopia, enophthalmos, progressive atrophy of the orbit and ocular motor nerve dysfunction [6].

A case history of a 12-year-old boy with progressive facial hemiatrophy, syringomyelia and epileptic seizures preceded by headaches is presented herein.

\section{Case report}

Two years ago a 10 -year-old boy with PRS was admitted to the Department of Paediatric Neurology, Chair of Paediatric and Adolescent Neurology, because of extremely severe headache attacks associated with vomiting, which appeared a few days before hospitalization. Since birth progressive left facial hemiatrophy has been observed in this boy. Delivery and pregnancy were uncomplicated and psychomotor development was normal. Family history of neurological disorders including migraine and epilepsy was negative. Two years earlier the boy suffered from meningitis of unknown aetiology.

Physical examination on admission revealed left facial hemiatrophy including skin, subcutaneous tissue and bone structures. Hyperpigmentation of subocular region and cheek, left enophthalmos and smaller eyeball were observed. The patient had retrognathia, gothic palate and limitation of jaw movements to the sides. Abnormalities of the skeletal system involved a short neck with limited dorsal flexion, side flexion and rotation, limited movement in the humeral joint and pathological gait pattern (with forward bending of the head and trunk). Thorough skin examination revealed café-au-lait spots on the trunk (about 12 small ones, a few millimetres in diameter, and 5 bigger ones, $2 \times 2 \mathrm{~cm}$ ), lower limbs (a few small ones and 2 bigger ones, $5 \times 5 \mathrm{~cm}$ ) and freckles in the axillary fossa.

Examination of the cranial nerves revealed paresis of the right abducens nerve with diplopia more promi- nent when looking to the right side. These findings, however, were transient and were not observed during subsequent hospitalizations. Function of other cranial nerves was not disturbed. Muscle tone and strength as well as deep tendon reflexes were normal. Meningeal signs were absent.

Due to the intense headache attacks and presence of neurological symptoms, organic type of headache had to be excluded first. Thorough neuroimaging diagnostics was performed. Magnetic resonance (MR) of the head revealed numerous abnormalities concerning soft tissues and bone structures of the left affected side of the head (Fig. 1). The results were similar to those of the examination performed 2 years earlier. The abnormal tissue partly covered the hypoplastic maxillary sinus and left part of the sphenoid sinus and masticatory area, and propagated toward the left orbit and middle cranial fossa, in the close vicinity of the temporal lobe. Further propagation toward the middle ear and mastoid process was observed. Moreover, the pathological mass entered the posterior cranial fossa with slight compression of the left cerebellar lobe. Proton MR spectroscopy of this area suggested ischaemia or necrobiosis. MR of the orbits did not show penetration of the abnormal tissue into the left orbit. MR scans of the brain were normal. Apart from that, an inflammatory process in the left frontal and maxillary sinus was present. MR scans of the cervical part of the spinal cord showed Arnold-Chiari malformation type I and syringomyelia (Fig. 2). MR angiography examination revealed reduction of middle cerebral arteries' peripheral branches and pathological course of vertebral arteries (right vertebral artery elongated and curved, crossing to the left side, left vertebral artery adjacent to the left lateral part of the medulla oblongata and inferior part of the pons, with slight compression) and asymmetry of posterior communicating arteries. None of those abnormalities could explain the headache attacks of the patient.

During hospitalization severe headaches associated with sweating and reddening of the face, hot flushes and hyperventilation were observed several times. Moreover, three of such headache attacks were followed by partial complex seizures. Characteristics of patient symptoms are provided in Table 1. Headache characteristics indicated migraine but presence of paroxysmal autonomic symptoms and complex partial seizures suggested an epileptic background of the symptoms. The interictal EEG pattern revealed localized discharges (sharp waves and single sharp and slow wave complexes) in the right posterior-temporal-parieto-occipital region (Fig. 3), with a tendency to 
synchronization during hyperventilation and photostimulation. Psychogenic aetiology of the headache attacks was also considered due to good response to placebo. The boy underwent psychological evaluation. High level of neuroticism, need of acceptance and attention paid by others were revealed. Some of the symptoms could be induced or intensified by the patient, but psychogenic aetiology could not explain all of them. In conclusion, a final diagnosis of epilepsy was established and antiepileptic treatment with carbamazepine was instituted (13 mg/kg/day) with initial good effect: subsidence of headache attacks and epileptic seizures for one month. During the next two months the boy was admitted to the local hospital four times due to recurring headache attacks and epileptic seizures (usually complex partial and three times secondary generalized tonic seizures). All of the epileptic seizures were preceded by headache attacks accompanied by autonomic symptoms and hyperventilation and usually occurred in the morning. One of the observed generalized tonic seizures was prolonged and lasted up to 15 minutes. Some headache attacks subsided after placebo. The carbamazepine dose was increased (18 $\mathrm{mg} / \mathrm{kg} / \mathrm{day}$ ). On the following day, the boy was admitted to our department and similar headache attacks, sometimes followed by epileptic seizures (usually complex partial, once a generalized tonic seizure) were observed. Carbamazepine was replaced by oxcarbazepine (27 mg/kg/day). After treatment modification headaches were observed several times but were less intense and subsided without treatment, usually during interactions with other patients.

Nevertheless, one week later the boy was admitted to our department again due to recurrent headaches and blurred margins of optic discs. Control MR of head and orbits did not differ significantly from the previous examinations. Another control ophthalmological examination performed two weeks later was normal. Visual evoked potentials were recorded and revealed elongation of P100 latency over the left hemisphere. Values of brainstem and somatosensory evoked potentials were within normal limits. Oxcarbazepine dose was increased to $32 \mathrm{mg} / \mathrm{kg} /$ day. Since the last hospitalization no headache attacks or epileptic seizures have been observed during 12 months.

\section{Discussion}

PRS is a rare condition of unknown pathophysiology. An autoimmunological process, inflammatory reaction, dysfunction of the autonomic nervous system or tri-

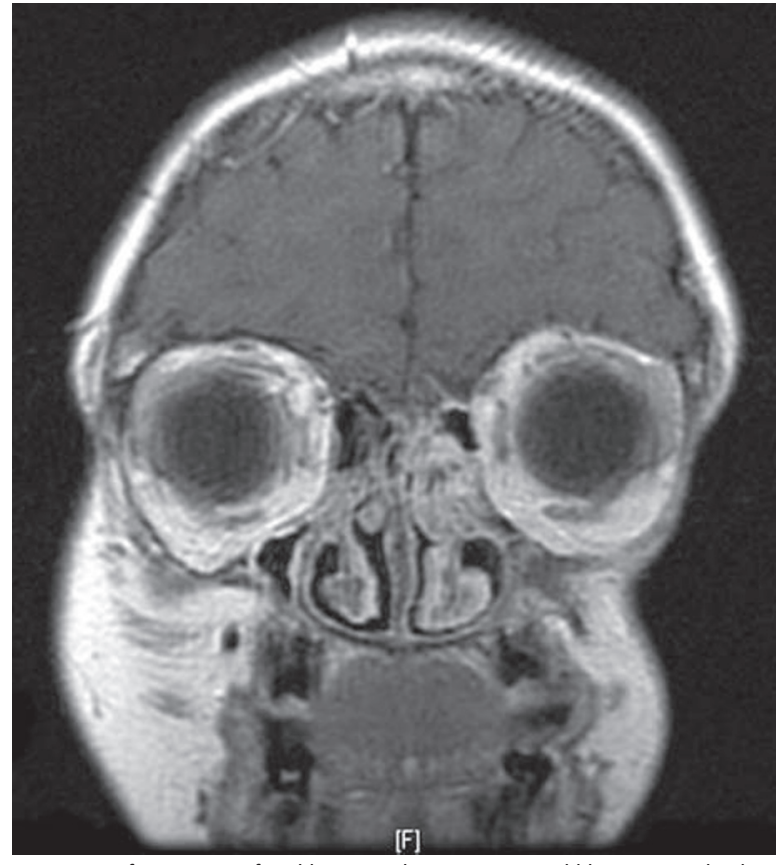

Fig. 1. Left progressive facial hemiatrophy in a 10-year-old boy. T1-weighted MR image in coronal plane after injection of gadolinium

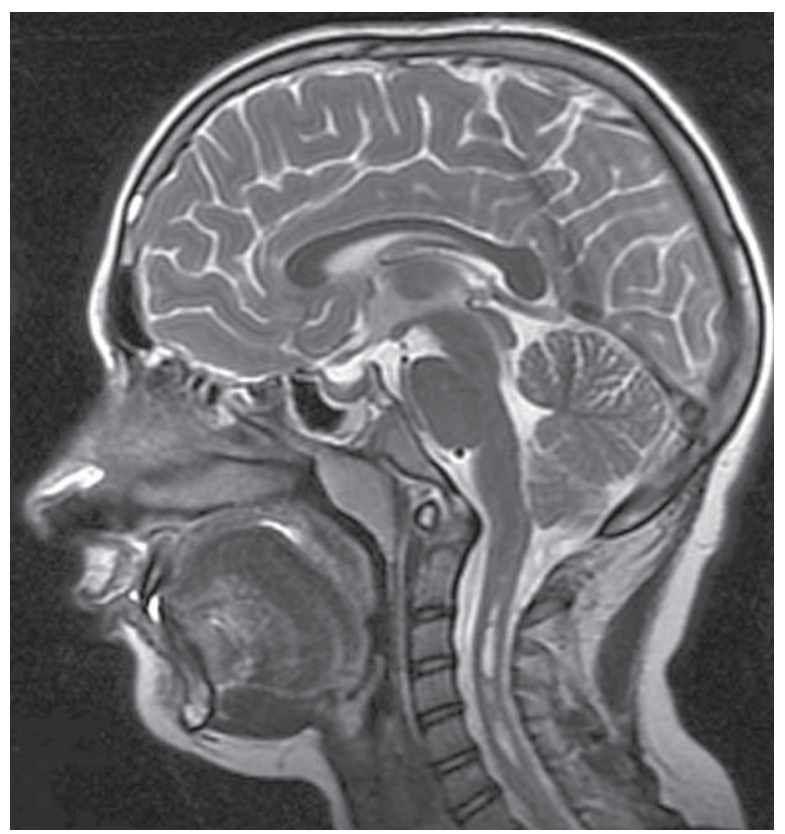

Fig. 2. Cervical syringomyelia in a 10-year-old boy with progressive facial hemiatrophy. T2-weighted MR image in sagittal plane

geminal nerve and neurodevelopmental impairment may be involved. Familial occurrence of this syndrome has also been reported [7]. PRS requires differentiation with other disorders leading to hemifacial deformations such as linear scleroderma "en coup de sabre" (LS). In LS, the pathological process is usually located over the 


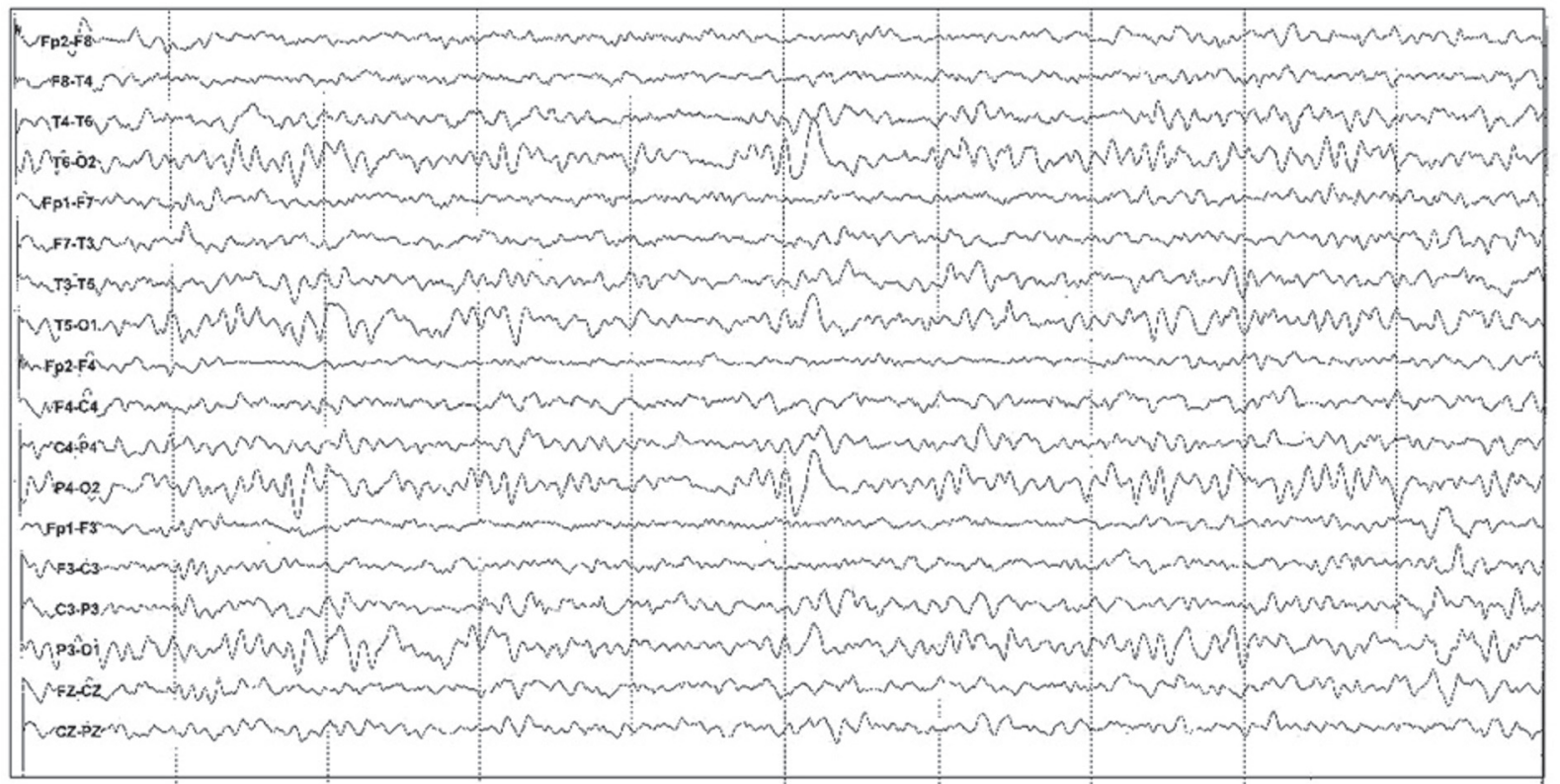

Fig. 3. Interictal EEG pattern: localized discharges of sharp waves and single sharp and slow wave complexes, in right posterior-temporal-parieto-occipital region

Table 1. Characteristics of paroxysmal symptoms in the boy with facial hemiatrophy

\begin{tabular}{|c|c|}
\hline $\begin{array}{l}\text { Age at onset } \\
\text { of the headache }\end{array}$ & 10 \\
\hline $\begin{array}{l}\text { Frequency } \\
\text { of the headache }\end{array}$ & $\begin{array}{l}\text { At the beginning, every day; after treatment institution, 3-4 times a week; after final treatment modification, } \\
\text { less than once a week }\end{array}$ \\
\hline $\begin{array}{l}\text { Duration of the } \\
\text { headache }\end{array}$ & $1-3$ hours \\
\hline $\begin{array}{l}\text { Time of headache } \\
\text { occurrence }\end{array}$ & Usually in the morning \\
\hline $\begin{array}{l}\text { Remission } \\
\text { of the headache }\end{array}$ & 1 month \\
\hline Headache location & Biparietal or frontal midline region \\
\hline Headache features & $\begin{array}{l}\text { Very intense, pressing or stabbing, aggravated by routine physical activity, head movements, cough or sneezing, } \\
\text { sometimes induced by physical activity or stress }\end{array}$ \\
\hline $\begin{array}{l}\text { Associated } \\
\text { symptoms }\end{array}$ & $\begin{array}{l}\text { Photo- and/or phonophobia, nausea or vomiting, blurred vision, diplopia, numbness of right arm or leg, motor } \\
\text { weakness of both legs (once), disturbed balance, } \\
\text { reddening, sweating of the face, hot flushes, crying, hyperventilation }\end{array}$ \\
\hline Epileptic seizures & $\begin{array}{l}\text { Sometimes followed by complex partial seizures (decreased level of consciousness, agitation) and four times } \\
\text { by secondarily generalized tonic seizures }\end{array}$ \\
\hline $\begin{array}{l}\text { Treatment of } \\
\text { headache attacks }\end{array}$ & $\begin{array}{l}\text { Oral paracetamol ineffective, oral ibuprofen }(7 \mathrm{mg} / \mathrm{kg}) \text { ineffective, intravenous metamizole ( } 30 \mathrm{mg} / \mathrm{kg}) \\
\text { ineffective, placebo sometimes effective }\end{array}$ \\
\hline $\begin{array}{l}\text { Antiepileptic } \\
\text { treatment }\end{array}$ & $\begin{array}{l}\text { Carbamazepine ( } 13 \mathrm{mg} / \mathrm{kg} / \mathrm{day}) \text { with temporary effect (complete control of epileptic seizures } \\
\text { and headache attacks for } 1 \text { month, then recurrence of the symptoms), dose increase }(18 \mathrm{mg} / \mathrm{kg} / \text { day) ineffective } \\
\text { Oxcarbazepine ( } 27 \mathrm{mg} / \mathrm{kg} \text { ) with complete control of the seizures (observation period: } 3 \mathrm{months} \text { and continues), } \\
\text { temporary control of headache attacks for two and a half weeks, after dose increase ( } 32 \mathrm{mg} / \mathrm{kg} / \mathrm{day}) \text {, complete } \\
\text { control of headache attacks and epileptic seizures }\end{array}$ \\
\hline
\end{tabular}


eyebrows in the fronto-parietal region and the affected skin is very hard in contrast to atrophic, thin skin in PRS. Typical cases of PRS and LS were described by BerglerCzop et al. [8]. However, some features overlap between these two entities, e.g. hemifacial location, ipsilateral brain lesions, and similar neurological symptoms such as epilepsy and migraine, leading to misdiagnosis [9-11]. Moreover, PRS and LS are considered by some authors as different clinical manifestations of the same disease and are thought to share similar pathogenesis. Menascu et al. [11] reported a case of a 13-year-old boy diagnosed with PRS, who was admitted due to status migrainosus. MR of the brain revealed white matter lesions in the fronto-parietal region and thinning of the overlying skin and bone. Three years earlier he was diagnosed with LS, based on clinical manifestation of the skin lesion and results of the skin biopsy.

There are no diagnostic criteria enabling distinction between these diseases. Neuroimaging and neuropathological results are also inconclusive. Hemifacial atrophy of the presented patient was progressing slowly since birth, and was not previously diagnosed. Impairment of the cranial neural crest may be a possible pathogenetic mechanism in this case [12]. The character and location of the hemifacial deformation (thin, soft skin, located beneath the eyebrow), and involvement of underlying bone structures indicate diagnosis of PRS rather than LS.

Occurrence of migraine and trigeminalgia in patients with PRS suggests the role of autonomic and trigeminal nerve impairment in its pathogenesis. Based on an Internet survey, Stone et al. [13] revealed high frequency of migraine and facial pain in patients with PRS ( $52 \%$ and $46 \%$ respectively).

Hyperreactivity of the sympathetic nervous system in PRS is suggested by some authors $[2,14]$. The superior cervical ganglion, medial and lateral internal carotid plexus, and their distal branches innervating cerebral arteries may be involved in this mechanism. It is possible that an inflammatory process triggers chronic sympathetic activity causing unilateral facial tissue destruction. Drummond et al. [14] performed an objective examination of the trigeminal nerve and sympathetic nervous system in a patient with PRS, ipsilateral migraine and trigeminalgia. Sympathetic hyperactivity was revealed on the affected side. Bergler-Czop et al. [8] also reported a patient with PRS who suffered from one-sided facial pain and ipsilateral headache with no changes in MR angiography. Moreover, status migrainosus was described in a patient with PRS syndrome, with normal MR angiography. However, cases with migraine and coexisting different intracranial vessel abnormalities have also been described, and usually they were located on the side of the facial hemiatrophy $[15,16]$. Woolfenden et al. reported a case with hemiplegic migraine and reversible irregular cerebral artery branches on the symptomatic side [15]. Pichiecchio et al. also described a patient with hemiplegic migraine and saccular aneurysm of the middle cerebral artery on the affected side [16].

The patient admitted to our clinic was suffering from headache attacks fulfilling the criteria of migraine with aura (ICHD-2, 1.2) (more than 5 attacks, lasting 1-3 hours, severe pain, aggravated by physical activity, associated with phono- and photophobia, nausea or vomiting, sometimes presence of fully reversible visual and sensory neurological deficits) [17]. MR angiography revealed only mild middle cerebral and vertebral artery abnormalities. Control head MR examination when compared to the previous one performed two years earlier enabled us to exclude progression of existing pathological tissues as a cause of the symptoms. Presence of a mild inflammatory process in the left paranasal sinuses in the absence of signs of infection as well as the paroxysmal character of the headaches eliminated sinusitis as a cause of the symptoms. Psychogenic background of the headaches was also considered in regard to their cessation after placebo or interactions with other patients. However, it is known that migraineurs have a special type of personality with a high level of emotional lability and stress and emotions can be one of the migraine trigger factors [18]. Psychological evaluation of the patient revealed the possibility of induction or aggravation of some of the symptoms but psychogenic aetiology cannot be the only explanation.

An additional feature indicating involvement of the autonomic nervous system in the reported case was presence of reddening, sweating of the face and hot flushes. Association of headaches with unilateral autonomic symptoms is present in trigeminal autonomic cephalalgias (cluster headache, paroxysmal hemicrania or SUNCT) [17]. Trigeminal nerve nucleus activation and cranial parasympathetic outflow through the trigeminal-autonomic reflex are involved in their pathomechanism. However, autonomic symptoms in the reported patient were bilateral, so another explanation must be sought. Paroxysmal occurrence may indicate their epileptic origin. They can be considered as the vegetative part of an epileptic attack or as an isolated equivalent of epilepsy. Association of headache attacks and epi- 
lepsy should be analysed in the case. ICHD II distinguishes headache attacks attributed to epilepsy such as hemicrania epileptica, where the headache attack accompanies a simple partial seizure or in rare cases may be the only epileptic manifestation and the final diagnosis is based on ictal EEG pattern, and postictal headache [17]. On the other hand, induction of an epileptic seizure by a headache attack is possible (migraine-triggered seizure) [17]. In the reported case, epileptic seizures were always preceded by headaches, autonomic symptoms and hyperventilation.

PRS is frequently associated with epilepsy, most often focal, and particularly sensory focal. In some patients epilepsy is easily controlled, but in others is drug-resistant and requires surgical treatment $[19,20]$. On the basis of histological study of resected brain tissue of a patient with focal epilepsy, vascular dysgenesis was suggested, referring to the neurodevelopmental theory of this syndrome [19]. After surgical treatment, patients were seizure-free, which suggested the presence of an epileptic focus within the resected tissue [20]. Complex partial seizures sometimes followed by generalized tonic seizures were observed in the patient presented here. There were no brain lesions indicating an epileptic focus; however, propagation of pathological tissue into the middle and posterior cranial fossa, next to the left temporal lobe and with slight compression of the left cerebellar lobe, may be considered as a triggering zone.

During the patient's stay in our department, only short secondarily generalized tonic seizures were observed. A generalized tonic seizure with prolonged course was reported by the local hospital. Elongation of the seizure might have been due to hyperventilation preceding the attack, which lowered the epileptic threshold and aggravated paroxysmal activity of the cortex.

Brain pathologies are commonly found in PRS. Castañeda-Reyna et al. described a 20-year-old man with facial hemiatrophy and refractory epilepsy. The MR of the head apart from deformations due to Parry-Romberg syndrome revealed atrophy of the dura mater and cystic leukoencephalopathy on the affected side [21]. Calcifications ipsilateral to the facial hemiatrophy and other brain lesions (focal infarctions, diffuse white matter signal changes, cortical thickening, leptomeningeal enhancement) were described in a 5.5-year-old patient by Cory et al. [2]. Pathogenetically, even correlation with Rasmussen disease was proposed [22]. Paprocka et al. [9] described a patient with refractory epilepsy and hemiparesis who was initially considered to have Rasmussen disease, which needs to be taken into acco- unt in differential diagnosis of this syndrome. Contrary to these reports, no brain lesions were found in our 12-year-old patient.

However, MR scans of the cervical spine revealed syringomyelia, which in our estimation is the first report of PRS associated with this lesion. A case of PRS with syringobulbia was reported in 1979 [23]. Involvement of this lesion in the pathophysiology of PRS in the presented patient with no motor-sensory signs or other spinal dysfunction is doubtful

In conclusion, we believe that in the presented case the possible pathomechanism of PRS is impairment of the cranial neural crest and resulting dysfunction of the autonomic nervous system. Migraine-like headache could be caused by increased cerebral vasoreactivity due to sympathetic hyperactivity. Epileptic attacks were always preceded by headaches, which may be considered as a triggering factor in this case. Interesting correlation of headache attacks, autonomic symptoms and epileptic seizures was observed in this patient with PRS.

\section{Disclosure}

Authors report no conflict of interest.

\section{References}

1. Yano T., Sawaishi Y., Toyono M., et al. Progressive facial hemiatrophy after epileptic seizures. Pediatr Neurol 2000; 23: 164-166.

2. Cory R.C., Clayman D.A., Faillace W.J., et al. Clinical and radiologic findings in progressive facial hemiatrophy (ParryRomberg syndrome). AJNR Am J Neuradiol 1997; 18: 751-757.

3. Miao J., Liu R., Lin H., et al. Severe bilateral pyramidal tract involvement in a patient with Parry-Romberg syndrome. Am J Med Sci 2009; 337: 212-214.

4. Sathornsumetee S., Schanberg L., Rabinovich E., et al. ParryRomberg syndrome with fatal brain stem involvement. J Pediatr 2005; 146: 429-431.

5. Rafai M.A., Boulaajaj F.Z., El Moutawakil B., et al. ParryRomberg syndrome with dysphonia. Rev Neurol (Paris) 2007; 163: 1246-1248.

6. Zubcov-Iwantscheff A.A., Thomke F., Goebel H.H., et al. Eye movement involvement in Parry-Romberg syndrome: a clinicopathologic case report. Strabismus 2008; 16: 119-121.

7. Ignatowicz R., Michałowicz R., Kmieć T., et al. Rodzinne występowanie choroby Parry'ego-Romberga. Pol Tyg Lek 1985; 40: 47-49.

8. Bergler-Czop B., Lis-Święty A., Brzezińska-Wcisło L. Scleroderma linearis: hemiatrophia faciei progressiva (Parry-Romberg syndrome) without any changes in CNS and linear scleroderma "en coup de sabre" with CNS tumor. BMC Neurology 2009; 9: 39 . 
9. Paprocka J., Jamroz E., Adamek D., et al. Difficulties in differentiation of Parry-Romberg syndrome, unilateral facial sclerodermia, and Rasmussen syndrome. Childs Nero Syst 2006; 22: 409-415.

10. Błaszczyk M., Królicki L., Krasu M., et al. Progressive hemifacial hemiatrophy: central nervous system involvement and relationship with scleroderma en coup de sabre. $J$ Rheumatol 2003; 30: 1997-2004.

11. Menascu S., Padeh S., Hoffman C., et al. Parry-Romberg syndrome presenting as status migrainosus. Pediatric Neurology 2009; 40: 321-323.

12. Cohen M.M. Jr. Asymmetry: molecular, biologic, embryopathic, and clinical perspectives. Am J Med Genet 2001; 101: 292-314.

13. Stone J. Parry-Romberg syndrome. A global survey of 205 patients using the Internet. Neurology 2003; 61: 674-676.

14. Drummond P.D., Hassard S., Finch P.M. Trigeminal neuralgia, migraine and sympathetic hyperactivity in a patient with ParryRomberg syndrome. Cephalalgia 2006; 26: 1146-1149.

15. Woolfenden A.R., Tong D.C., Norbash A.M., et al. Progressive facial hemiatrophy: Abnormality of intracranial vasculature. Neurology 1998; 50: 1915-1917.

16. Pichiecchio A., Uggetti C., Egitto M.G., et al. Parry-Romberg syndrome with migraine and intracranial aneurysm. Neurology 2002; 59: 606-608.

17. Headache Classification Committee of The International Headache Society. The International Classification of Headache Disorders 2nd Edition. Cephalalgia 2004; 24 (Suppl 1): 1-160.

18. Wendorff J., Adam R., Durko A. Różnice czynników prowokujących napady migrenowe u dzieci, młodzieży i dorosłych. Neurol Dziec 2003; 12: 15-20.

19. Chbicheb M., Gelot A., Rivier F., et al. Parry-Romberg syndrome and epilepsy. Rev Neurol (Paris) 2005; 161: 92-97.

20. DeFelipe J., Segura T., Arellano J.I., et al. Neuropathological findings in a patient with epilepsy and the Parry-Romberg syndrome. Epilepsia 2001; 42: 1198-1203.

21. Castañeda-Reyna M.A., Galarza-Manyavi C. Parry Romberg syndrome associated with refractory epilepsy, atrophy of the dura mater and cystic leukoencephalopathy. Rev Neurol 2003; 37: 941-945.

22. Shah J.R., Juhász C., Kupsky W.J., et al. Rasmussen encephalitis associated with Parry-Romberg syndrome. Neurology 2003; 61: 395-397.

23. Tebloev I.K., Kalashnikov IuD. Pathogenesis of symptomatic facial hemiatrophy. Zh Nevropatol Psikhiatr Im S S Korsakova 1979; 79: 413-416. 